msh-mss Mathématiques et sciences humaines

146 | Été 1999

Varia

\title{
Orthotreillis et séparabilité dans un graphe non orienté
}

Ortholattices and separability in undirected graphs

Anne Berry et Jean-Paul Bordat

\section{CpenEdition}

1 Journals

Édition électronique

URL : http://journals.openedition.org/msh/2786

DOI : $10.4000 / \mathrm{msh} .2786$

ISSN : 1950-6821

Éditeur

Centre d'analyse et de mathématique sociales de l'EHESS

Édition imprimée

Date de publication : 1 mars 1999

ISSN : 0987-6936

Référence électronique

Anne Berry et Jean-Paul Bordat, "Orthotreillis et séparabilité dans un graphe non orienté »,

Mathématiques et sciences humaines [En ligne], 146 | Été 1999, mis en ligne le 10 février 2006, consulté le 23 juillet 2020. URL : http://journals.openedition.org/msh/2786 ; DOl : https://doi.org/10.4000/msh. 2786

Ce document a été généré automatiquement le 23 juillet 2020.

(c) École des hautes études en sciences sociales 


\title{
Orthotreillis et séparabilité dans un graphe non orienté
}

\author{
Ortholattices and separability in undirected graphs
}

Anne Berry et Jean-Paul Bordat

\section{RÉSUMÉS}

Nous présentons une généralisation de la notion de séparateur minimal dans un graphe non orienté, et nous montrons que ces séparateurs sont représentés par les rectangles maximaux de la matrice d'adjacence, structurés en un orthotreillis, que nous appelons treillis de séparabilité. Réciproquement, tant donné un orthotreillis, nous montrons qu'il n'existe pas en général un unique graphe minimal dont il serait treillis de séparabilité. Nous donnons une condition nécessaire et suffisante pour que cette dernière propriété soit vérifiée. Le dernier paragraphe de l'article contient des considérations algorithmiques relatives aux treillis orthocomplémentés.

We present a generalization of minimal separation in an undirected graph, and show how the maximal rectangles of the adjacency matrix describe such separators, and form an ortholattice, which we call the Separability Lattice. Furthermore, for any given ortholattice L, we show that there does not exist a unique minimal graph of which $\mathrm{L}$ is the Separability Lattice. We establish a necessary and sufficient condition for the existence of such a graph. The end of the paper deals with algorithmic considerations on the class of orthocom-plemented lattices. 
INDEX

Thèmes : graphes, ordres et préordres, permutations, treillis

Keywords: Galois lattice, graph, ortholattice, separability lattice, separator

Mots-clés : graphe, orthotreillis, séparateur, treillis de Galois, treillis de séparabilité 